\title{
Regional Policy and Spillovers from FDI in the UK
}

\author{
Nigel Driffield, \\ Birmingham Business School, \\ Ashley Building, \\ Birmingham University, \\ Edgbaston, \\ Birmingham. \\ B15 2TT
}

\begin{abstract}
.
This paper tests one of the fundamental assumptions of regional policy makers over the last 20 years. Western governments, in seeking to attract internationally mobile capital have spent significant sums of public money on subsidies and grants. This is justified on the basis that the social returns to FDI are significantly greater than the private returns, due to productivity or technology spillovers from inward investors to domestic industry. However, this paper generates some estimates of these spillovers for both assisted areas and non-assisted areas in the UK, and questions the size of these social returns, arguing that productivity spillovers do not occur in regions where significant inward investment incentives are available.
\end{abstract}

Keywords : FDI, spillovers, regional policy

JEL classification : O33, R58

\footnotetext{
* Thanks are due to Holger Gorg, Sourafel Girma, Jim Love, Max Munday, Nigel Pain, Jim Taylor, Colin Wren and to seminar participants in Cardiff, Lancaster and London for comments on an earlier version of this paper.
} 


\section{INTRODUCTION.}

This paper examines one of the basic tenets of regional policy in both the developing and developed world over the past 20 years. This concerns the assumption that providing subsidies in order to attract inward investment to a country or region confers beneficial externalities on the host country or region that are over and above the direct employment gain. It is clear that the major rationale for local or regional Development Agencies seeking to attract foreign direct investment is the direct employment gain. It is also clear that in both the US and Europe, the "cost per job” of the investment incentives offered cannot be justified on the basis of the number of jobs directly associated with the investment alone. Morgan (1997) for example illustrates that the rationale of attracting inward investment has been firmly based on the assumption that certain indirect benefits from FDI will accrue to the domestic sector, in the form of technological, or productivity externalities. If this is the case, then the social returns to such investments are significant and may justify the large subsidies. This paper however will argue that that inward investment does very little to contribute to productivity growth in the domestic sector, and that any benefit where the inward investment is attracted through subsidy is negligible.

Inward investment policies have been based on the assumed causal link between inward investment and regional development. The argument for subsidising inward investment is based on 'superior' multinational enterprises (MNEs) entering the domestic industry, and their advantages somehow being assimilated by the domestic sector. Part of this explanation is based on inter-industry adjustment, including a reallocation of resources to industry sectors of above average industry comparative advantage. On a regional level, new foreign manufacturing investment can also have beneficial economic consequences. In addition to job creation and resource transfer, foreign inward investments can also provide 
technology and skills transfer to supplier and customer sectors. Multinational enterprise may then provide a basis for technology spillovers and the development of innovatory capacity in domestically owned sectors (Blomström and Kokko, 1996).

There is evidence that spillovers do accrue to the domestic sector as a result of inward FDI, but only under certain circumstances, see for example Blomström et al (2001), or Markusen and Venables (1999). Blomström et al (2001) however argue that the regions in possession of significant location advantages, will be those best placed to gain most from the foreign presence. However, as Morgan (1997) notes, the policy of subsidising inward investment was designed to address the symptoms of regional disparities, such as unemployment, rather than the underlying causes, such as low levels of technological development.

The remainder of the paper is divided as follows. Section two discusses inward investment policy and its likely effects, while section three discusses the potentially beneficial effects of inward investment. Section four develops the model along fairly standard lines, based on an augmented production function approach to test for the existence of externalities. Section five discusses the data and presents some descriptive statistics, and section six is then devoted to outlining some of the econometric issues with such models. Finally, sections seven and eight are devoted to results and conclusions.

\section{SUBSIDY FOR INWARD INVESTMENT IN THE UK.}

Western governments have spent significant sums of public money in attracting inward investment, and indeed it may even be argued that attracting (and retaining) inward investment has been the main focus of industrial and regional policy in the UK. The merits of various approaches to regional policy are discussed in some detail in Armstrong and Taylor (1993). Leaving aside the issue of whether governments should intervene to address regional disparity, the theoretical literature on regional policy makes one essential distinction. This 
focuses on the debate concerning whether regional policy should be designed to address the symptoms of regional disparity such as unemployment and low levels of investment, or whether it should seek to address the underlying causes, such as low productivity and low levels of innovation. Largely, UK regional policy has been concerned to identify regions with high levels of unemployment that could benefit from new fixed capital formation. ${ }^{\mathrm{i}}$ A detailed description of the types of instruments that have been employed in the UK under the aegis of regional policy, are described for example in Armstrong (2001), DTI (2001) Harris and Robinson (2001) and the Armstrong and Taylor (1993).The main instrument that has been employed in the UK since the early 1980s is Regional Selective Assistance (RSA). This was introduced in 1972, and is discussed in detail in many standard texts, such as Armstrong and Taylor (1993).

Taylor and Wren (1997) trace in some depth the changes in the administration of UK regional policy from the 1970s onwards, demonstrating that total spending on regional policy declined from $0.4 \%$ of GDP in the early 1980 s, to $0.1 \%$ by the late 1990 s. This apparent reduction is ascribed to a combination of better targeting of spending (and greater onus on the recipient firms to justify explicitly the need for support), and greater reliance on EU structural funds for the implementation of regional policy, albeit within the same assisted areas ${ }^{\mathrm{ii}}$. This period also saw a more careful redrafting of the Assisted Areas map in the UK, to target areas best placed to gain from such funding. As Wren (2002) demonstrates, regional assistance is much reduced compared with 25 years ago, with much stricter eligibility criteria, but it still essentially takes the form of investment subsidies to the private sector ${ }^{\mathrm{iii}}$. As such, regional policy and attracting internationally mobile capital, particularly in assisted areas, have become synonymous.

As Harris and Robinson (2001) outline in some detail, RSA is a capital subsidy designed to stimulate employment in regions with above average unemployment. ${ }^{\text {iv }}$. Recipients of RSA 
must be operating in Assisted Areas, and in practice most recipients have been in the manufacturing sector. Harris and Robinson (2001) provide a detailed breakdown by sector of the recipients of RSA, showing that RSA recipients accounted for an average of $8.4 \%$ of manufacturing employment over the period 1990-1998. RSA is concentrated in larger firms, and by definition in the peripheral areas of the UK. In Wales and Scotland for example, RSA recipients account for approximately a quarter of manufacturing employment, while the corresponding figures for the North of England and the West Midlands were $18.7 \%$ and 11.7\% respectively. Harris and Robinson (2001) also show that RSA is over-represented among foreign establishments. This is perhaps not surprising, and fits with the stylised "fact" of MNEs being attracted by subsidies, particularly to areas of high unemployment and (therefore) low wages. This is discussed at length in Munday et al (2001).

For the time period with which this paper is largely concerned, there were 11 Standard Planning regions of the $\mathrm{UK}^{\mathrm{V}}$, and the following table provides an indication of the relative size of the assisted areas within each region ${ }^{\mathrm{vi}}$. Table 1 illustrates the extent to which one can make a distinction between "assisted area” and "non-assisted area” regions, with very large proportions of the peripheral areas of the UK (Northern Ireland, Wales, Scotland and the North of England) being covered by assisted areas status. 
Table 1. The importance of Assisted Area status by region.

\begin{tabular}{|l|l|l|l|l|l|l|l|l|}
\hline & \multicolumn{3}{|l|}{$\begin{array}{l}\text { Share of total regional employment } \\
\text { that is within assisted areas }\end{array}$} & \multicolumn{3}{|l|}{$\begin{array}{l}\text { Share of foreign-owned employment } \\
\text { regional that is within assisted areas }\end{array}$} \\
\hline & 1984 & 1988 & 1992 & 1996 & 1984 & 1988 & 1992 & 1996 \\
\hline North & $83 \%$ & $81 \%$ & $84 \%$ & $84 \%$ & $81 \%$ & $80 \%$ & $71 \%$ & $73 \%$ \\
\hline $\begin{array}{l}\text { Yorkshire \& } \\
\text { Humberside }\end{array}$ & $17 \%$ & $9 \%$ & $7 \%$ & $6 \%$ & $18 \%$ & $6 \%$ & $9 \%$ & $6 \%$ \\
\hline $\begin{array}{l}\text { East } \\
\text { Midlands }\end{array}$ & $3 \%$ & $3 \%$ & $4 \%$ & $3 \%$ & $2 \%$ & $1 \%$ & $3 \%$ & $4 \%$ \\
\hline East Anglia & 0 & 0 & 0 & 0 & 0 & 0 & 0 & 0 \\
\hline South East & 0 & 0 & 0 & 0 & 0 & 0 & 0 & 0 \\
\hline South West & $14 \%$ & $8 \%$ & $8 \%$ & 0 & $5 \%$ & $1 \%$ & $3 \%$ & 0 \\
\hline $\begin{array}{l}\text { West } \\
\text { Midlands }\end{array}$ & $72 \%$ & $72 \%$ & $72 \%$ & $58 \%$ & $71 \%$ & $70 \%$ & $65 \%$ & $60 \%$ \\
\hline North West & $43 \%$ & $46 \%$ & $54 \%$ & $59 \%$ & $46 \%$ & $46 \%$ & $66 \%$ & $67 \%$ \\
\hline Wales & $96 \%$ & $94 \%$ & $98 \%$ & $96 \%$ & $98 \%$ & $96 \%$ & $94 \%$ & $96 \%$ \\
\hline Scotland & $76 \%$ & $72 \%$ & $73 \%$ & $71 \%$ & $80 \%$ & $79 \%$ & $70 \%$ & $73 \%$ \\
\hline $\begin{array}{l}\text { Northern } \\
\text { Ireland }\end{array}$ & $100 \%$ & $100 \%$ & $100 \%$ & $100 \%$ & $100 \%$ & $100 \%$ & $100 \%$ & $100 \%$ \\
\hline
\end{tabular}

Source: Report on the Census of Production, and UK Office of National Statistics, various years

This illustrates the clear distinction between those regions that are able to offer investment incentives (to foreign or domestic companies) and those that are not. Regions with assisted area status are able to offer greater financial incentives to potential investors (both domestic and foreign), and thus would be expected to attract large proportions of new inward investment. Nijkamp and Blaas (1995) demonstrate for example that the European Regional Development Fund has influenced private investment rates across European Regions. Wren and Taylor (1999) go one stage further, demonstrating that investment incentives have had the effect of changing the regional distribution of economic activity across the UK in general. It is clear that investment incentives have had the effect of encouraging firms to locate in away from regions that demonstrate more obvious location advantage.

Table 2, illustrating nominal productivity across the foreign and domestic firms across assisted areas and non-assisted areas provides an alternative comparison between assisted 
areas and non-assisted area regions. There is a discernable productivity gap between foreign and domestic firms, and between assisted areas and non-assisted areas, but this gap did not widen over the period.

Table 2. Productivity estimates for the foreign and domestic sectors.

\begin{tabular}{|c|c|c|c|c|c|c|c|c|}
\hline & \multicolumn{4}{|c|}{ Domestic sector } & \multicolumn{4}{c|}{ Foreign sector } \\
\hline & 1984 & 1988 & 1992 & 1996 & 1984 & 1988 & 1992 & 1996 \\
\hline Non-assisted areas & 21268 & 33079 & 35945 & 38989 & 31918 & 47352 & 53492 & 57842 \\
\hline Assisted areas ${ }^{\text {viii }}$ & 19951 & 30574 & 32729 & 34500 & 28026 & 41395 & 45162 & 48122 \\
\hline
\end{tabular}

Value added/ manual worker, money values. Source, UK Office of National Statistics

Table 2 also illustrates one of the points made by Morgan (1997), that regions with large scale assisted area status are those characterised by low levels of capital intensity, and low levels of skill intensity, as well as lower levels of value added.

Figures 1 and 2 illustrate the regional dispersion of FDI across the UK, and also the extent to which this is concentrated in areas where financial assistance is available. Inward investment in several regions is heavily concentrated in assisted areas, particularly in the peripheral regions of the UK, such as Wales, Northern Ireland and the North of England. Clearly the South East is the dominant region in terms of attracting FDI, while 3 other regions have significantly increased their inward investment flows, most notably the East Midlands which saw investment by foreign firms increase by more than $500 \%$ over the period.

\section{Figures 1 and 2 here}

Figure 3 illustrates the importance of FDI for regional development, illustrating that inward investment accounts for some 35\% of new capital expenditure in UK manufacturing. FDI is not evenly distributed across the UK, with inward investment in many of the 
peripheral areas of the UK accounting for as much as half of total investment. This proportion was rising throughout the period.

\section{Figure 3 here}

The figures and tables presented here suggest many of the direct benefits to a host country of attracting inward investment, most of which are well understood. Inward investment will act to improve aggregate productivity as foreign firms in the UK a demonstrable productivity advantage over domestic UK firms, and indeed Davies and Lyons (1992) examine this in some detail. It is also likely that inward investment will improve the host country's balance of payments position by increasing exports as well as engaging in import substitution, and that productivity will increase as resources are reallocated to more efficient producers. All of this is secondary however to the fundamental justification for subsidising inward investment, which is to generate employment. Many studies have argued however that the size of subsidies employed to attract inward investment cannot be justified in terms of direct and indirect employment alone, that an addition externality in the form of productivity growth in the domestic sector must occur for such subsidies to be cost effective.

\section{THE POTENTIAL FOR SPILLOVERS FROM INWARD INVESTMENT.}

Blomström and Kokko (1996) provide several reasons why technology is expected to transfer from MNEs to domestic firms. This can occur directly, through the licensing of a particular technology, through supplier networks or subcontracting arrangements, or indirectly as knowledge becomes public and spillovers are assimilated by the domestic sector.

However, these models of the impact of FDI, also assume an adverse effect on the domestic sector. Markusen and Venables (1999) outline the two main impacts on local firms of inward investment, as do Aitken and Harrison (1999). In addition to the standard productivity gains argument, Aitken and Harrison (1999) explain a further impact of a large 
MNE entering an industry. The foreign firm captures some of the domestic firms' market shares, forcing them to operate at a smaller scale, reducing output and (possibly) increasing unit cost. This is expected to be significant in imperfectly competitive markets, and is similar to the result reported by Driffield and Munday $(1998)^{\mathrm{ix}}$.

Buffie (1993) expresses particular concerns that inward investment simply has the effect of reducing domestic output. Holden and Swales (1995) discuss the importance of displacement, particularly in the context of regional policy. They show that, with the advent of more discretionary investment or employment subsidies, then the impact on the incumbent firms may be greater than otherwise anticipated, and displacement of such output or employment increased.

Given the existence of a foreign productivity advantage, productivity or technological spillovers from inward investment are dependent on two phenomena. Following the arguments by Blomström and Kokko (1996), Driffield (2001) or Porter (1996) for example, the scale and scope of spillovers from inward investment are determined by the ability of the domestic sector to assimilate the imported technology, and the extent to which agglomeration contributes to this. As such, domestic firms in the less technologically advanced regions of the UK may be less able to assimilate the new technology that may accompany FDI. The regions with assisted area status are also by definition those with high levels of unemployment, and a low skill base, so expansion through technological advance may be hindered in such regions. As such therefore, while previous studies suggest that spillovers may occur as a result of FDI, such externalities may be confined to those areas with a higher skill base, and with higher levels of productivity, viz. the areas of the UK not covered by Assisted Area status. Secondly, Assisted Areas are by definition less likely to generate agglomeration economies, and so by encouraging inward investment away from the core regions, much of the potential indirect benefit from FDI may be lost. 
In a similar vein, there is significant evidence that such Development Agencies are not only actively competing to attract international capital (Lovering (1999), Young et al (1994), Gripaios et al (1997)), but in more recent years have been concerned to contain any spillovers from FDI within their region. Wren (2002) outlines examples of these policies, designed to increase the scale and scope of local spillovers from $\mathrm{FDI}^{\mathrm{x}}$. However, while the extent to which such policies are likely to succeed has been questioned, Armstrong (2001), Wren (2002), it is never the less clear that such agencies have sought where possible to maximise local linkages from inward investment. Porter (1996) argues that policies designed to increase local sourcing will lead to a loss in overall agglomeration economies and will be to the detriment of other regions and possibly to the economy as a whole. As Porter (1996) shows, such effects are likely to be exacerbated where the location advantage (to which the MNE was initially attracted) has taken the form of an investment subsidy, rather than endowment based sources of comparative advantage. For technology spillovers to be assimilated by the domestic firms, the domestic sector must be sufficiently technologically advanced. While this is often a problem associated with developing countries, it is never the less still a problem in the West, Blomström (2000), Driffield (2001).

Based on the above discussion, it is possible to outline several hypotheses:

- One would expect spillovers to occur as a result of inward investment, however:

- These are likely to be limited geographically, and less likely to be significant across industries.

- The “crowding out” or competitive effect may outweigh any positive technology effect at the industry level.

- Spillovers will be greater where FDI has not simply been attracted by subsidy, and as such likely to be greater in non-assisted areas. 
This paper therefore employs three measures of inward investment penetration: The first is a measure of FDI within the industry and the region of the domestic firm. The second measures FDI that occurs within the industry of the investment across all other regions, while the third is inward investment that occurs across all other industries within the region of the domestic firm. These three measures then capture three potential spillover effects, a local industryspecific effect, a general regional effect and a national industry level effect.

\section{MEASUREMENT OF PRODUCTIVITY EXTERNALITIES.}

There is a relatively large literature, following Caballero and Lyons (1989, 1990, 1992), which essentially seeks to encompass the spillovers at an industry level that occur as a result of an increase in external output expansions. The general approach employed in the spillovers literature, is to begin with an augmented production function of the following type:

$\log \mathrm{Q}_{\text {irt }}=\mathrm{a}+\beta_{1} \ln \left(\mathrm{K}_{\mathrm{irt}}\right)+\beta_{2} \ln \left(\mathrm{NL}_{\mathrm{irt}}\right)+\beta_{3} \ln \left(\mathrm{ML}_{\mathrm{irt}}\right)+\mu_{\mathrm{t}}+\sum_{k=1}^{n} \alpha_{k} X_{\text {irt }}+\mathrm{u}_{\text {irt }} \ldots .(1)$

Where Q represents output, K represents the capital stock of the firm; labour is divided into manual (ML) and non-manual labour (NL). The subscripts i, $\mathrm{r}$ and t refer to industry, region and time respectively. This therefore relates the vector of externalities to total factor productivity growth in the sector concerned. This methodology is discussed at length in Griliches and Lichtenberg (1984), and more specifically in the context of spillovers from FDI in Aitken and Harrison (1999) or Driffield (2001). Domestic total factor productivity in equation 1 is therefore related to the stock of foreign owned capital as the externality variable. Crucially, the measure of foreign investment employed here is the stock of capital in foreign owned or controlled firms. This is calculated on a perpetual inventory method using net capital expenditure with a $10 \%$ depreciation rate. The model therefore relates total factor productivity in the domestic sector, to the stock of inward investment. Given how the stock of 
inward investment is calculated, this places more weight on new investment. This also therefore excludes capital flows that occur simply as a result of acquisitions for example.

Oulton (1996) discusses at length the potential problems with this approach, although many of these are essentially accounting problems at the macro level. One of the potential problems is that the error term from equation (1) may be related to aggregate output growth, thus deriving spurious evidence of externalities. The papers by Oulton (1996) and others, following Caballero and Lyons (1990) however, are concerned with a more general form of externality than that considered here. The focus here is a more specific question, the existence of spillovers from inward investment, rather than whether output spillovers exist per se. The sources of potential investment spillovers here are tightly defined and a causal relationship between FDI and domestic productivity growth is assumed, so it is unlikely that the 'spillover' variable will be related to the error term ${ }^{\mathrm{xi}}$.

\section{ECONOMETRIC CONSIDERATIONS}

The usefulness of panel data for estimating productivity growth is now well understood, based on the initial work of Mankiw et al (1992), or in the context of industrial economics studies of externalities, on Caballero and Lyons (1989, 1990, 1992). In addition however, Islam (1992) shows that a dynamic specification is appropriate, as growth is in part dependent on past performance, and past input levels.

$\ln Q_{\text {irt }}=\mathrm{a}+\gamma \ln \mathrm{Q}_{\mathrm{irt}-1}+\beta_{1} \ln \left(\mathrm{K}_{\mathrm{irt}}\right)+\beta_{2} \ln \left(\mathrm{NL}_{\mathrm{irt}}\right)+\beta_{3} \ln \left(\mathrm{ML}_{\mathrm{irt}}\right)+\mu \mathrm{t}+\sum_{k=4}^{6} \beta_{k} X_{\mathrm{irt}-1}+\mathrm{v}_{\mathrm{irt}} \ldots .(2)$

where $\mathrm{X}$ is the vector of externalities from FDI outlined above and $\mathrm{t}$ is a time trend, included as a proxy for exogenous technological change.

However, it is then suggested that there are time specific, and observation (industry) specific effects. 
Such that $\mathrm{v}_{\text {irt }}=\alpha_{\mathrm{ir}}+\mu_{\mathrm{t}}+\mathrm{u}_{\mathrm{irt}}$

The standard manner of estimating this, with such panel data, is to convert (2) to first differences, to remove the individual effects, which by construction are correlated with the lagged dependent variable, and estimate the 'fixed effects' model.

$\Delta \ln Q_{\text {irt }}=\gamma \Delta \ln Q_{\text {irt- } 1}+\beta_{1} \Delta \ln \left(\mathrm{K}_{\mathrm{irt}}\right)+\beta_{2} \Delta \ln \left(\mathrm{NL}_{\mathrm{irt}}\right)+\beta_{3} \Delta \ln \left(\mathrm{ML}_{\mathrm{irt}}\right)+\mu+\sum_{k=4}^{6} \beta_{k} \Delta X_{\text {irt }-1}$ $+\mathrm{u}_{\mathrm{irt}} \ldots .(4)$

As such therefore, domestic total factor productivity growth is related to lagged changes in the (log of the) stock of FDI.

As is well understood, the GMM estimator suggested by Arellano and Bond $(1988,1991)$ can be applied to estimate (4), which generates heteroscedastic-consistent estimates. The lagged dependent variable becomes endogenous and so must be instrumented using further lags. There is a concern that with this type of estimation of what is essentially a "growth" model, that the estimate of the coefficient on the lagged dependent variable has an upward bias, if the panel data exhibits significant heterogeneity, see Pesaran and Smith (1995). There is no definitive test for this, and the various suggested estimators are designed for panels with a long time series, but narrow cross sections, see for example Lee et al (1998) who discuss the application of the "mean group” estimator. Lee et al (1995) however also show that biased estimates may be produced with the mean group estimator for $\mathrm{T}$ as large as 30 . One possible test with these data is to allow for slope dummies in the lagged dependent variable, allowing $\gamma$ to vary across industries or across regions. Standard specification tests however reject the inclusion of such variables, suggesting that heterogeneity is not a problem.

The essential purpose of this paper is to determine whether productivity spillovers that occur as a result of inward investment are different for assisted areas (that is areas that subsidise 
inward investment) and non-assisted areas. There are numerous ways of addressing this, one could estimate equation (4) for the full sample, and test whether $\beta_{4}, \beta_{5}$ and $\beta_{6}$ differ (either jointly or separately) between assisted areas and non-assisted areas. This however presents a problem. As is well understood, assisted areas are characterised by high levels of unemployment and low levels of investment. However, it is generally argued that these are merely symptoms of the underlying problems such as low productivity growth, low skill levels and low levels of technological development. It is inappropriate therefore in a model of productivity growth to treat assisted areas status as an exogenous variable (as a region's assisted areas status is partly determined by past levels of output or productivity). This would also involve imposing a restriction of the same production function coefficients across assisted areas and non-assisted areas' industries, which again is likely to be an invalid restriction. The appropriate methodology is therefore to divide the sample using the endogenous variable (assisted areas status) and estimate (4) for the two sub-samples separately. This is discussed further in section 7.

\section{THE DATA}

The data used here are industry and regional level data for the UK, covering 1984$1997^{\mathrm{xii}}$. For the first (second) part of the sample there are 20 (23) manufacturing sectors, 11 (11) standard planning regions, and, giving 220 (243) observations per year. The advantage of such data, is that they allow one to evaluate inter- and intra-regional effects, as well as inter-, and intra- industry effects. The measures of inward investment that are then used as potential sources of externalities are; foreign investment at the regional level, at the industry level, and also at the industry and regional level. The data were gathered from the Annual Production Inquiry (formerly the Census of Production), and directly from the UK Office of 
National Statistics, who provided the data on the foreign owned sector alone, to allow the calculation of the domestically owned sector.

All monetary values of data used in the econometric analysis are in real terms (1984 prices), deflated by the relevant sectoral level consumer price index (available on Datastream).

Q represents domestic industry output: this is measured using gross value added of the domestic sector at the industry and regional level.

$\mathrm{K}$ is the capital stock of the domestic industry. This is calculated using a perpetual inventory method employing capital expenditure (i.e. real investment) data over the previous 3 years. A depreciation rate of $10 \%$ is used, and the data expressed in real terms.

ML is employment of manual workers (operatives) in domestic owned industry at the regional and industry level.

NL is employment of non-manual workers (non-operatives) in domestic owned industry at the regional and industry level.

For the latter sample, there is no distinction between manual and non-manual workers, so labour enters the production function as a single input, L.

Measures of inward investment.

The stock of foreign capital is calculated using a perpetual inventory method employing capital expenditure (i.e. real investment) data over the previous 3 years. A depreciation rate of $10 \%$ is used, and the data expressed in real terms.

Three measures of inward investment penetration are then included in the analysis. These are all included in log form in the regressions. 


\begin{tabular}{|l|l|}
\hline FDI & $\begin{array}{l}\text { The stock of foreign capital in the relevant industry and region for the } \\
\text { previous year. }\end{array}$ \\
\hline FDI $_{\text {it }}$ & $\begin{array}{l}\text { The stock of foreign capital in the relevant industry across all regions } \\
\text { for the previous year. }\end{array}$ \\
\hline FDI $_{\mathrm{rt}}$ & $\begin{array}{l}\text { The stock of foreign capital in the relevant region across all industries } \\
\text { for the previous year. }\end{array}$ \\
\hline
\end{tabular}

\section{RESULTS.}

Equation (4) was estimated for the assisted and non-assisted areas separately. The North West region was omitted from both samples, as it clearly lies between the 2 categories. It would be erroneous to include the North West as a non-assisted area, but equally a large proportion of inward investment in the North West has not attracted RSA. Sensitivity analysis indicates that including the North West in either group does not change the results or inferences significantly in either direction. The results derived for the two sub-samples are given in tables 4 and 5 .

\section{Table 4 \& 5 here}

For both sub-samples, the (internal) production function variables behave much as expected and all are significant. The results are also consistent across the two time periods. However, there is significantly more evidence of exogenous technological change in the "non assisted areas” group, suggesting that productivity growth may be faster here than in the peripheral areas of the UK. There is also evidence that skilled labour generates a greater proportion of value added in the non-assisted areas than in the assisted areas, which are more likely to be unskilled-labour intensive. The lagged dependent variable has a greater value for the non-assisted sample, suggesting that past performance is a more important determinant of total factor productivity in the non-assisted areas sample. Overall, standard specification tests reject the restriction of imposing a single production function on these two groups, suggesting that the technology employed in domestic industry differs between assisted areas and nonassisted areas. 
The main result from a policy perspective is that there is evidence at the regional level of spillovers from FDI. The coefficient on FDI irt is significant and positive for the nonassisted group, suggesting that FDI generates productivity growth within the same industry and region as the investment. However, while the coefficient on FDI irt approaches significance for the latter sample of assisted areas, overall these results suggest that these spillovers are confined to the non-assisted area regions of the UK. This is the variable that theoretically is most likely to demonstrate an externality, as it is both industry, and region specific. It is interesting that for the later sample, this coefficient is positive, though small and barely significant. This suggests that spillovers from FDI in assisted areas may well have increased in recent years, though only at a local intra-industry level. Turning to the more general measures of productivity externalities through FDI, the results are in line with what is expected. The coefficient on $\mathrm{FDI}_{\mathrm{it}}$, that is the measure of FDI that is only industry-specific, is consistent across the two groups. In both cases, the coefficient is negative, and is suggestive of the crowding out effect, outlined by Aitken and Harrison (1999) or Buffie (1993). Specifically, this result suggests that FDI generates a short term loss in productivity at the industry level, due to a reduction in scale of the domestic sector, following expansion of the foreign owned sector. These results also suggest that FDI, in say the South East of England, will have a detrimental effect on industries in peripheral regions, which is directly opposite to the aim of regional policy and the use of investment incentives. Finally, the region-specific measure of FDI again perhaps not surprisingly, provides tentative evidence of productivity growth following FDI at the regional level, but again only for non assisted areas. This is rather worrying, as assisted area regions tend to be on the periphery of the UK, Wales, Northern Ireland, Scotland and the North of England for example, and it is these areas that have spent sizable amounts attracting inward investment. ${ }^{\text {xiii }}$ There is no apparent difference in these results between the two time frames. This is perhaps surprising, given the greater 
emphasis on targeting of projects that local agencies have placed on subsidies on recent years, with accompanying policies designed to boost spillovers within the local economy.

\section{CONCLUSION}

The impact of inward investment on productivity growth or technological advance has been of interest for some time, particularly given the large investment incentives that are offered to multinational companies to locate in particular regions. These results suggest that spillovers from FDI do occur, but are only significant where the inward investment is motivated by the desire to exploit firm specific advantages generated elsewhere. Even in this case, the beneficial effects are limited to the region that has been able to attract the investment. There is also evidence that inward investment exerts a negative impact on productivity growth in the domestic sector. This may only be short term, but is suggestive of the crowding out effect exerted by inward investors on domestic firms. It is of course possible that in welfare terms, this particular adverse effect may be offset in the long term through an overall increase in allocative efficiency, and through balance of payments gains.

The evidence presented here not only raises concerns regarding the social returns of spending public money on attracting inward investment, but also questions the extent to which inward investment can contribute to regional development beyond the direct employment effects. This mirrors the concerns expressed by Porter (1996), that where the main motivation for attracting FDI are investment incentives then inward investment makes only a negligible contribution to regional development. From a policy perspective this raises several challenges for local development agencies. Firstly, there is some evidence that the increased targeting of projects, and tighter criteria for firms receiving subsidies has acted to improve the social returns to inward investment. This would suggest that more should be done locally to "embed" inward investment into the domestic economy, not only as purchasers of local output, but also suppliers to local firms. In this way, the technology 
inherent in the FDI will transferred more efficiently to domestic producers. There is clearly a role here for development agencies becoming more active in encouraging knowledge transfers within the locality rather than merely as suppliers of subsidy. There is evidence that policy is moving in this direction, but as yet there is only limited evidence of technological externalities flowing from this. 


\section{REFERENCES}

Aitken, Brian, Gordon H. Hanson, Ann E. Harrison, (1997) Spillovers, foreign investment, and export behavior, Journal Of International Economics (43)1-2 pp. 103-132

Aitken, Brian.J. and Anne.E. Harrison, (1999). Do domestic firms benefit from direct foreign investment? Evidence from Venezuela ? American Economic Review 89 (3): 605-618.

Arellano, Miguel. and Stephen Bond, (1988) Dynamic panel data estimation using DPD, a guide for users. Institute for Fiscal Studies working paper.

Arellano, Miguel. and Stephen Bond,. (1991) 'Some tests of specification for panel data: Monte Carlo evidence and an application to employment equations'. Review of Economic Studies, Vol. 58 pp. 277-97.

Armstrong, Harvey W. (2001) Regional selective assistance. Is the spend enough and is it targeted in the right places? Regional Studies, Vol. 35 (3) pp. 247-57

Armstrong, H.W. Jim Taylor (1993) Regional economics and policy. $2^{\text {nd }}$ edition, Harvester Wheatsheaf London.

Baltagi, Badi. H. (1995) Econometric analysis of panel data, Wiley.

Blomström, Magnus., Steven Globerman, and Ari Kokko, (2001) “The determinants of host country spillovers from FDI”. In Nigel Pain (ed.) Inward investment, technological change and growth. MacMillan, London.

Blomström, Magnus . and Ari Kokko (1996) 'Multinational corporations and spillovers.' CEPR discussion paper no 1365.

Blomström, Magnus . and Ari Kokko. (2000) “Outward Investment, Employment and Wages in Swedish Multinationals". Presented at the conference on "Globalisation and Labour Markets” Nottingham University, $7^{\text {th }}$ July 2000.

Buffie, Edward F. (1993), "Direct Foreign Investment, Crowding Out, and Underemployment on the Dualistic Economy”. Oxford Economic Papers 45(4), October 1993, pp.639-67.

Caballero, Ricardo. J. and Richard K. Lyons, (1989) 'The role of external economies in US manufacturing.’ NBER working paper no. 3033.

Caballero, Ricardo. J. and Richard K. Lyons (1990) 'Internal versus external economies in European industry.’ European Economic Review, Vol. 34, No. 4, pp. 805-30.

Caballero, Ricardo. J. and Richard K. Lyons (1992) 'External effects in US procyclical productivity.’ Journal of Monetary Economics, Vol. 29, No. 2, pp. 209-225.

Davies, Stephen.W. and Bruce R Lyons, (1991) Characterising relative performance: The productivity advantage of foreign owned firms in the UK. Oxford Economic Papers -new series. vol. 43 no 4 pp 584-595 
Driffield, Nigel L (1999). 'The indirect employment effects of FDI into the UK'. Bulletin of Economic Research, Vol. 51(3) pp. 207-222.

Driffield, Nigel L. (2001) 'The impact on domestic productivity of inward investment in the UK.’ Manchester School, Vol. 69(1) pp. 103-119

Driffield, Nigel .L. and Max. C. Munday, (1998) 'The Impact of Foreign Direct Investment on UK Manufacturing: Is there a profit squeeze in domestic firms?’ Applied Economics, Vol. 30, pp. 705-7090.

DTI (2000) Evaluation of regional selective assistance, 1991-1995, Report Produced for the DTI / Scottish Executive/ Welsh Assembly.

Griliches, Zvi. and Frank Lichtenberg, (1984) 'Interindustry technology flows and productivity growth: A reexamination.'. Review of Economics and Statistics, Vol. 66, No. 2, pp. 324-29.

Gripaios, Peter., Rose Gripaios, and Max Munday, M. (1997) 'The role of inward investment and urban economic development: The cases of Bristol, Cardiff and Plymouth.' Urban Studies, Vol. 34(4) pp. 567-603.

Harris, Richard and Catherine Robinson (2002) An analysis of Current DTI industry support patterns. A report for the UK Department of Trade and Industry, available at: http://www.dur.ac.uk/richard.harris/

Holden, Darryl .R. and J.K. Swales, (1995) "The additionality, displacemnt and substitution effects of factor subsidies.” Scottish Journal of Political Economy, Vol.42, (2) pp. 113-126.

Islam, Nazrul. (1995) 'Growth empirics, a panel data approach.' Quarterly Journal of Economics, Vol. 60, pp. 1127-1170.

Lee, Kevin, M. Hashem Pesaran, and Ron Smith, (1995) 'Growth and convergence in a multi-country empirical stochastic Solow model.’ Journal of Applied Econometrics, Vol. 12, pp. 357-392.

Lee, K., Pesaran, M.H., and Smith, R. (1998) 'Growth empirics, a panel data approach - a comment.’ Quarterly Journal of Economics, Vol. 63, pp. 319-323.

Lovering, John. (1999), 'Theory led by policy: The inadequacies of the 'new regionalism' (illustrated from the case of Wales)' International journal of urban and regional research, Vol.23 (2) pp.379-395

Mankiw, N. Gregory, David Romer, and David N. Weil, (1992) 'A contribution to the empirics of economic growth’. Quarterly Journal of Economics, Vol. 72, pp. 407-37.

Markusen, James. and Venables, Anthony. J. (1999), "Foreign Direct Investment as a Catalyst for Industrial Development.” European Economic Review 43 pp.335-356.

Morgan, Kevin. (1997) 'The learning region: Institutions, innovation and regional renewal.’ Regional Studies, 31 pp. 491-503. 
Munday, Max, David Pickernell and Annette Roberts (2001) Regional Policy effectiveness and local governance issues: Some Welsh perspectives. Policy Studies Vol. 22(1) pp. 51-60.

Nijkamp, Peter. and Eddy Blaas, (1995) 'Comparative regional policy analysis: Ex post valuation of the performance of the European Regional Development Fund.' Journal of Regional Science, Vol. 35 (4), pp. 579-597.

Oulton, Nicholas. (1996) 'Increasing returns and externalities in UK manufacturing : Myth or reality ?’ Journal of Industrial Economics, Vol. 44, No. 1, pp. 99-113.

Pesaran, M.H., and Smith, R. (1995) 'Estimating long run relationships from dynamic heterogeneous panels.’ Journal of Econometrics, Vol. 68, pp. 79-113.

Porter, Michael .E. (1996) 'Competitive advantage, agglomeration economies and regional policy’. International Regional Science Review, 19 (1): 85-90.

Swales, J Kim (1997) The ex post evaluation of regional selective assistance. Regional Studies, Vol. 31(9) pp. 859-865.

Taylor, Jim and Colin Wren (1997) UK regional Policy, an evaluation. Regional Studies Vol. 31(9) pp. 835-848.

Wren, Colin. (2002) UK regional policy, does it measure up? Mimeo, University of Newcastle upon Tyne.

Wren, Colin. and Taylor, Jim. (1999) ' Industrial restructuring and regional policy'. Oxford Economic Papers, Vol. 51, pp. 487-516.

Young, Steven., Hood, Neil. , and Peters, Ewen. (1994) 'Multinational enterprises and regional economic development.’ Regional Studies, Vol. 28 pp. 657-677. 
Figure 1: Foreign Investment into the UK by Region

Net capital expenditure by foreign owned firms, Emillion, money values

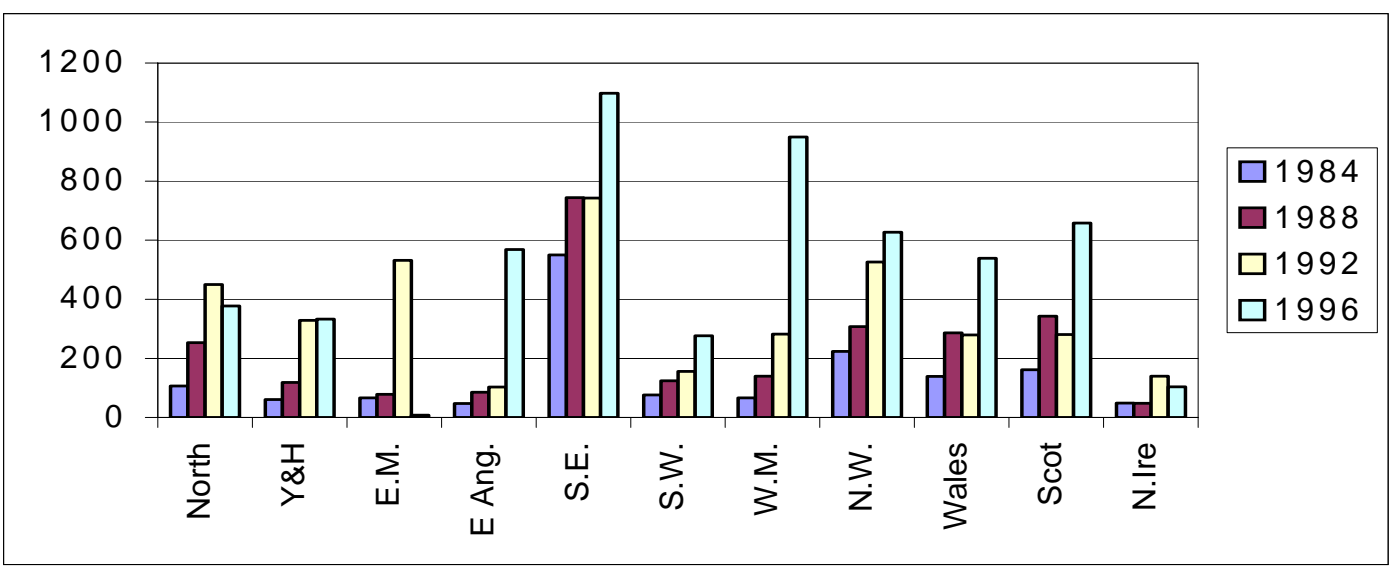

Figure 2: The importance of Regional assistance across areas:

Regional assistance as a percentage of value added across the regions

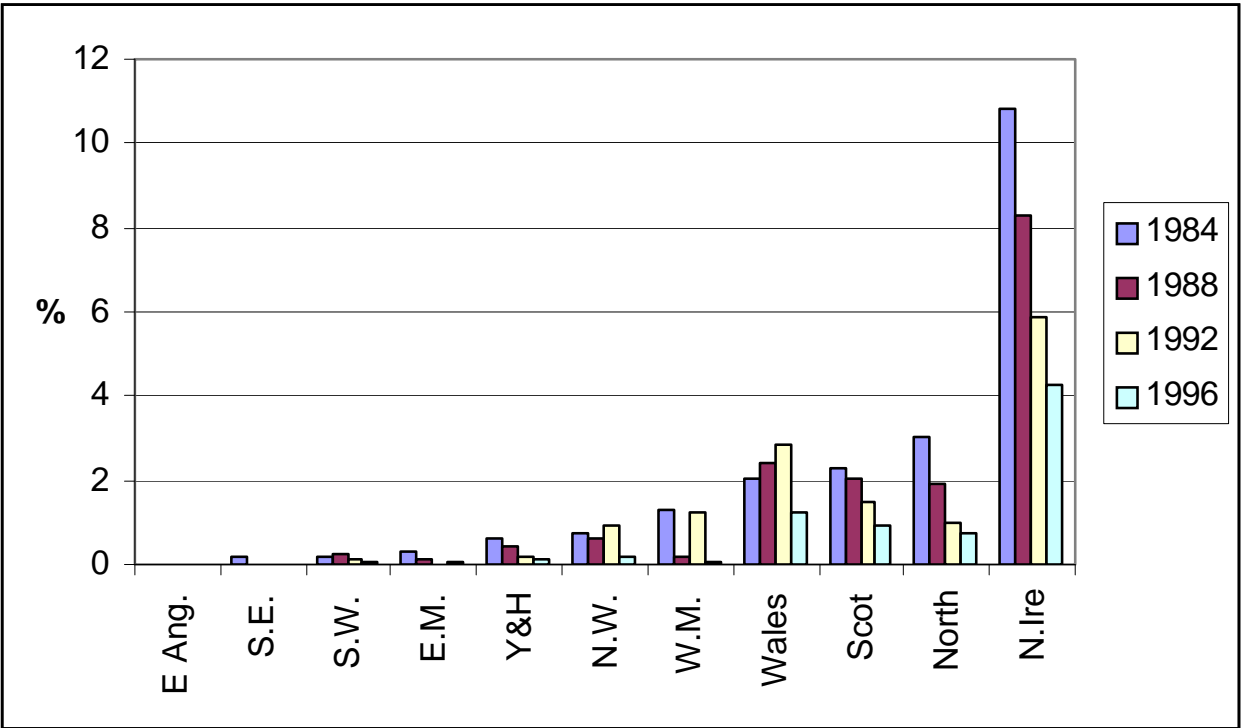


Figure 3. The importance of inward investment across Regions.

The percentage of net capital investment in the region carried out by foreign owned firms.

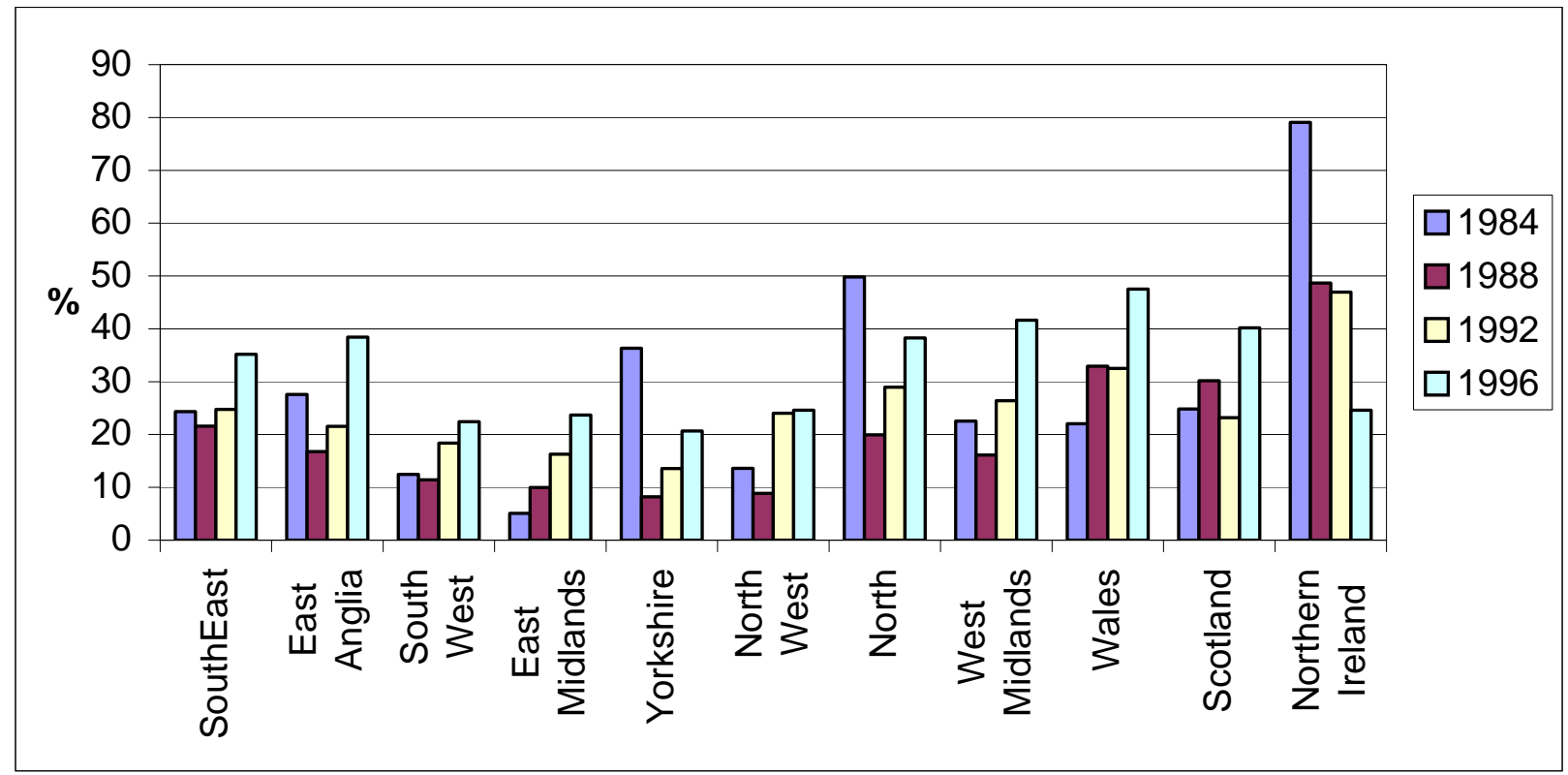


Table 4 : Results 1983-1992

\begin{tabular}{|c|c|c|}
\hline & Non-assisted areas & Assisted areas \\
\hline Variable & $\begin{array}{c}\text { coefficient } \\
\text { (t values) }\end{array}$ & $\begin{array}{c}\text { coefficient } \\
\text { (t values) }\end{array}$ \\
\hline time & $\begin{array}{c}0.124^{* *} \\
(2.56)\end{array}$ & $\begin{array}{c}0.051^{*} \\
(1.89)\end{array}$ \\
\hline $\mathrm{K}_{\mathrm{irt}}$ & $\begin{array}{c}0.153^{* *} \\
(5.08) \\
\end{array}$ & $\begin{array}{c}0.210^{* *} \\
(4.39) \\
\end{array}$ \\
\hline $\mathrm{NL}_{\text {irt }}$ & $\begin{array}{c}0.209 * * \\
(5.23) \\
\end{array}$ & $\begin{array}{c}0.144^{* *} \\
(5.24)\end{array}$ \\
\hline $\mathrm{ML}_{\text {irt }}$ & $\begin{array}{c}0.433^{* *} \\
(6.26) \\
\end{array}$ & $\begin{array}{c}0.449 * * \\
(5.15) \\
\end{array}$ \\
\hline $\mathrm{Q}_{\text {irt-1 }}$ & $\begin{array}{c}0.234^{* *} \\
(2.67)\end{array}$ & $\begin{array}{c}0.197^{* *} \\
(2.63)\end{array}$ \\
\hline FDI $_{\text {irt }}$ & $\begin{array}{c}0.063^{* *} \\
(2.43)\end{array}$ & $\begin{array}{c}-0.0013 \\
(0.85)\end{array}$ \\
\hline $\mathrm{FDI}_{\text {it }}$ & $\begin{array}{c}-0.034^{* *} \\
(2.01)\end{array}$ & $\begin{array}{c}-0.028^{* *} \\
(2.10)\end{array}$ \\
\hline $\mathrm{FDI}_{\mathrm{rt}}$ & $\begin{array}{c}0.029 * \\
(1.97)\end{array}$ & $\begin{array}{l}0.014 \\
(1.01)\end{array}$ \\
\hline $\begin{array}{ll}\text { Spatial } & \text { autocorrelation } \\
\text { (Morans I) } & \end{array}$ & $\begin{array}{c}1.151 \\
(0.250)\end{array}$ & $\begin{array}{c}1.128 \\
(0.259)\end{array}$ \\
\hline Time dummies & Yes & yes \\
\hline $\begin{array}{l}\text { Specification } \\
\chi^{2}(5)^{\mathrm{xiv}}\end{array}$ & $\begin{array}{c}5.187 \\
(p=0.394)\end{array}$ & $\begin{array}{c}8.472 \\
(p=0.132)\end{array}$ \\
\hline Sargan - p value & 0.544 & 0.465 \\
\hline $\begin{array}{l}\text { Inclusion of further lags of } \\
\text { FDI variables LR test } \chi^{2}(3)\end{array}$ & $\begin{array}{c}4.851 \\
(0.183)\end{array}$ & $\begin{array}{c}5.148 \\
(0.161)\end{array}$ \\
\hline $\begin{array}{l}\text { serial correlation } \\
\operatorname{AR}(2)^{\mathrm{xv}} \sim \chi^{2}(1)\end{array}$ & $\begin{array}{c}1.349 \\
p=0.245\end{array}$ & $\begin{array}{c}1.561 \\
p=0.2115\end{array}$ \\
\hline $\mathrm{N}$ (6 years) & $\begin{array}{c}660 \\
\text { (5 regions) }\end{array}$ & $\begin{array}{c}660 \\
\text { (5 regions) }\end{array}$ \\
\hline
\end{tabular}

One step heteroscedastic - consistent standard errors. 
Table 5 : Results 1993-1997

\begin{tabular}{|c|c|c|}
\hline & Non-assisted areas & Assisted areas \\
\hline Variable & $\begin{array}{c}\text { coefficient } \\
\text { (t values) }\end{array}$ & $\begin{array}{c}\text { coefficient } \\
\text { (t values) }\end{array}$ \\
\hline time & $\begin{array}{c}0.077^{* *} \\
(2.06)\end{array}$ & $\begin{array}{c}0.031 \\
(1.25) \\
\end{array}$ \\
\hline $\mathrm{K}_{\mathrm{irt}}$ & $\begin{array}{c}0.301^{* *} \\
(4.02)\end{array}$ & $\begin{array}{c}0.278^{* *} \\
(3.65)\end{array}$ \\
\hline$\overline{L_{\text {irt }}}$ & $\begin{array}{c}0.588^{* *} \\
(7.84)\end{array}$ & $\begin{array}{c}0.609^{* *} \\
(8.56)\end{array}$ \\
\hline Q $_{\text {irt-1 }}$ & $\begin{array}{c}0.088^{* *} \\
(2.02) \\
\end{array}$ & $\begin{array}{c}0.104^{* *} \\
(2.54) \\
\end{array}$ \\
\hline $\mathrm{FDI}_{\text {irt }}$ & $\begin{array}{c}0.088^{* *} \\
(3.17) \\
\end{array}$ & $\begin{array}{c}0.014 \\
(1.34)^{\mathrm{a}} \\
\end{array}$ \\
\hline $\mathrm{FDI}_{\mathrm{it}}$ & $\begin{array}{c}-0.027^{*} \\
(1.92)\end{array}$ & $\begin{array}{c}-0.041^{* *} \\
(2.09)\end{array}$ \\
\hline $\mathrm{FDI}_{\mathrm{rt}}$ & $\begin{array}{l}0.019^{*} \\
(1.88)\end{array}$ & $\begin{array}{l}0.008 \\
(0.67)\end{array}$ \\
\hline $\begin{array}{ll}\text { Spatial } & \text { autocorrelation } \\
\text { (Morans I) } & \end{array}$ & $\begin{array}{l}1.381 \\
(0.17)\end{array}$ & $\begin{array}{l}0.752 \\
(0.45)\end{array}$ \\
\hline Time dummies & Yes & yes \\
\hline $\begin{array}{l}\text { Specification } \\
\chi^{2}(4)\end{array}$ & $\begin{array}{c}4.863 \\
(0.302)\end{array}$ & $\begin{array}{c}5.964 \\
(0.202)\end{array}$ \\
\hline Sargan - p value & 0.254 & 0.657 \\
\hline $\begin{array}{l}\text { Inclusion of further lags of } \\
\text { FDI variables LR test } \chi^{2}(3)\end{array}$ & $\begin{array}{c}3.588 \\
(0.310) \\
\end{array}$ & $\begin{array}{c}2.485 \\
(0.478) \\
\end{array}$ \\
\hline $\begin{array}{l}\text { serial correlation } \\
\operatorname{AR}(2) \sim \chi^{2}(1)\end{array}$ & $\begin{array}{c}0.845 \\
(0.358) \\
\end{array}$ & $\begin{array}{c}0.982 \\
(0.322) \\
\end{array}$ \\
\hline $\mathrm{N}$ (2 years) & $\begin{array}{c}230 \\
5 \text { regions }\end{array}$ & $\begin{array}{c}230 \\
5 \text { regions } \\
\end{array}$ \\
\hline
\end{tabular}

One step heteroscedastic - consistent standard errors.

\footnotetext{
${ }^{\mathrm{i}}$ This recognises that there are certain areas of inner cities for example that may have above average unemployment, but that seeking to attract large scale investment is not feasible due to congestion or other constraints. This is an essential reason why regional policy is based on relatively large areas rather than very small jurisdictions.

ii The units of analysis for the assisted areas map are the UK administrative regions that are the NUTS2 areas for EU comparison. The UK “assisted areas" are therefore the NUTS2 regions that have either objective 1 or objective 2 area status under EU regulations.

iii The changes in the implementation of UK regional policy are discussed in great detail by Wren (2002).

iv A ceiling is usually applied in terms of the "cost per job”.

${ }^{\vee}$ This was increased to 13 in 1995 by separating London from the rest of the South East of England, and Merseyside from the rest of the North West of England.
}

\footnotetext{
${ }^{\mathrm{a}}$ The $\mathrm{p}$ value for this $\mathrm{t}$ statistic is 0.182
} 


\footnotetext{
vi The data that are used in this paper are from 1984 to 1992. There was a change in both regiona, and industry classifications in 1993, which breaks the series. There are not, as yet, sufficient years data available after ths break to allow the econometric analysis to be extended to the later period.

vii 1996 data are not published in this form. I am grateful to the DTI for the provision of the assisted areas/nonassisted areas split.

viii The data presented here includes the North West in the assisted area group, as clearly a firm considering investing in this region has access to assisted area funding. However, if one excludes this region from the figures in table 2, then the differentials between assisted and non-assisted are even more marked.

${ }^{\text {ix }}$ This phenomenon would still be expected in contestable markets. Theory suggests that firms in contestable markets operate at, or very close to their minimum effeicient scale. As such, entry by a (superior) MNE would result in a loss of market share for the domestic firm, thus forcing it back up its long run AC curve, increasing average costs.

${ }^{x}$ Initiatives such as 'source Wales' are an explicit example of this, as Morgan (1997) outlines in some detail.

${ }^{x i}$ See Oulton (1996) for a full discussion of this. Empirically this can be tested for using standard heteroskedasticity tests.

xii There was a change in regional and industry classifications in 1993 for the UK, preventing consistent extension of the data.

xiii Other variables, such as FDI in "related" industries (derived from input-output tables) or contiguous regions were also used, to test for inter-industry, or inter-regional effects. The $t$ values on these variables, even when employed in the absence of all others, were less than 0.8 , and so the variables were rejected from the regression. ${ }^{\text {xiv }}$ This is based on testing the Cobb-Douglas specification against a translog specification.

${ }^{\mathrm{xv}}$ This LM test is outlined on Baltagi (1995) pp. 93
} 